\title{
Visible or invisible atypical form of microscopic colitis with giant cells: for the endoscopist, that is the question
}

A 64-year-old woman was admitted to the hospital with complaints of recurrent non-intensive abdominal pain without watery diarrhea; she also complained of hand tremors and dizziness. The patient had a medical history of chronic primary adrenal insufficiency for 22 years. She was on steroid replacement therapy (hydrocortisone, fludrocortisone) at the time of presentation. Physical examination was unremarkable. Laboratory test results showed only a low level serum iron (4.1 micromole/L); others (including hemoglobin, C-reactive protein) were within normal limits. Human immunodeficiency virus serology and fecal culture were negative. Upper gastrointestinal (GI) endoscopy revealed atrophic gastritis features. Colonoscopy examination showed normal ileum mucosa with local erythematous spots of mucosa in the ascending colon ( $\vee$ Video 1, $\triangleright$ Fig. 1); a biopsy was performed simultaneously. Histopathological examination of the biopsy demonstrated an increased number of intraepithelial lymphocytes and normal crypt architecture with no clearly thickened subepithelial collagen layer. In addition, subepithelial multinucleated giant cells were present ( $\downarrow$ Fig. 2 a, b). No true granulomas, foreign material, or microorganisms were seen. Special stains for fungi and acid-fast bacilli were negative. An atypical form of microscopic colitis with giant cells was confirmed.

Microscopic colitis with giant cells is a rare atypical form of microscopic colitis characterized by the presence of multinucleated giant cells in an otherwise classic microscopic colitis without endoscopic and radiological abnormalities; its reported incidence is less than 3.7 to 4.1 cases per $10^{5}$ person-years [1]. Giant cell colitis was first described by Libbrecht et al. in 2002 [2]. The exact etiology of microscopic colitis is unknown, but a

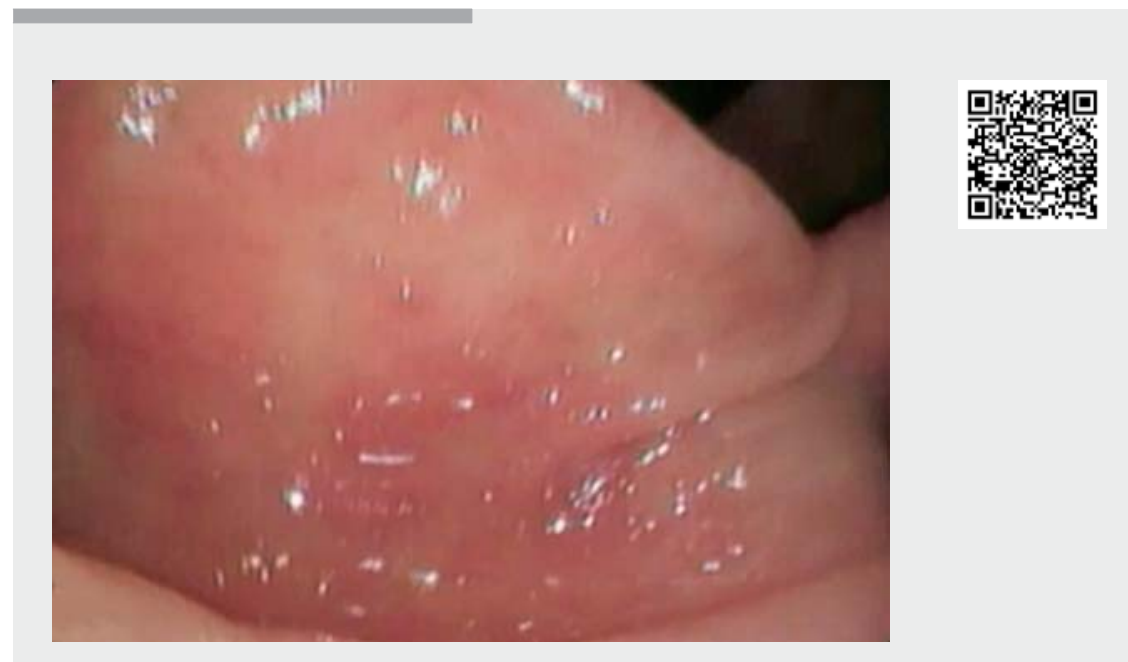

Video 1 Colonoscopy showing local flat erythematous spots of mucosa in the ascending colon with biopsy. Conclusion: local colitis.

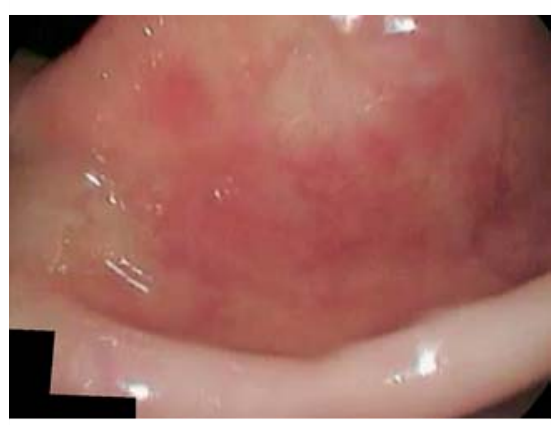

- Fig. 1 Colonoscopy photographs before biopsy demonstrate local flat erythematous spots of mucosa in the ascending colon in white-light imaging mode.

luminal factor triggering an abnormal reaction in predisposed patients has been implicated [3]. We electronically searched the PubMed database (January 2002 - January 2020) for the key words "microscopic colitis with giant cells" and found only 14 messages.

Endoscopy_UCTN_Code_CPL_1AN_2AD
Competing interests

The authors declare that they have no conflicts of interest.

The authors

Andrey P. Kiryukhin ${ }^{1}$, Pavel V. Pavlov ${ }^{1}$, Alexander A. Fedorenko ${ }^{1}$, Alexander $S$. Tertychnyy ${ }^{2}$, Tatiana L. Lapina ${ }^{3}$

1 Endoscopy Unit, The Second University Clinic, I. M. Sechenov First Moscow State Medical University (Sechenov University), Moscow, Russia

2 Department of Pathology, I. M. Sechenov First Moscow State Medical University (Sechenov University), Moscow, Russia

3 Department of Internal Diseases Propedeutics, Gastroenterology and Hepatology, I. M. Sechenov First Moscow State Medical University (Sechenov University), Moscow, Russia 


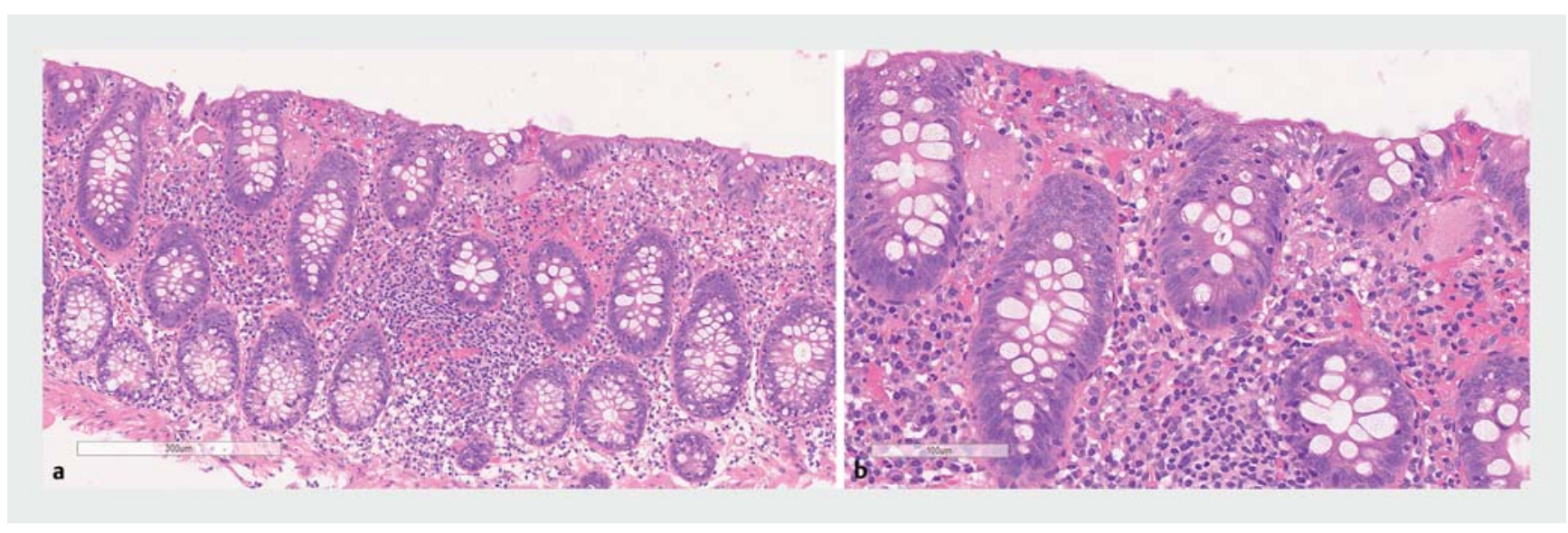

- Fig. 2 a Histopathological section revealed increased number of intraepithelial lymphocytes with normal crypt architecture and subepithelial multinucleated giant cells (hematoxylin and eosin stain); image $\times 200$. b Histopathological section revealed increased number of intraepithelial lymphocytes with normal crypt architecture and subepithelial multinucleated giant cells (hematoxylin and eosin stain); image $\times 400$.

\section{Corresponding author}

\section{Andrey P. Kiryukhin, MD}

Endoscopy Unit, The Second University Clinic, I. M. Sechenov First Moscow State Medical University (Sechenov University), 1 build. 1, Pogodinskaya St., 119435 , Moscow, Russia a.p.kiryukhin@gmail.com Fax: +7-903-5066135

\section{References}

[1] Chang F, Deere H, Vu C. Atypical forms of microscopic colitis: morphological features and review of the literature. Adv Anat Pathol 2005; 12: 203-211
[2] Libbrecht L, Croes R, Ectors N et al. Microscopic colitis with giant cells. Histopathology 2002; 40: 335-338

[3] Bohr J, Olesen M, Tysk C et al. Collagenous and lymphocytic colitis: a clinical and histopathological review. Can J Gastroenterol 2000; 14: 943-947

\section{Bibliography}

Endoscopy 2020; 52: E404-E405

DOI $10.1055 / \mathrm{a}-1149-1286$

ISSN 0013-726X

published online 17.4 .2020

(c) 2020. Thieme. All rights reserved.

Georg Thieme Verlag KG, Rüdigerstraße 14, 70469 Stuttgart, Germany

\section{ENDOSCOPY E-VIDEOS}

https://eref.thieme.de/e-videos

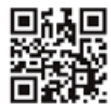

Endoscopy E-Videos is a free access online section, reporting on interesting cases and new

techniques in gastroenterological endoscopy. All papers include a high quality video and all contributions are freely accessible online.

This section has its own submission website at

https://mc.manuscriptcentral.com/e-videos 